\title{
Capitalism and Its New-Old Religion: a Civil Economy Perspective
}

\author{
Luigino Bruni*
}

Lumsa University, Rome, Italy

Received February 05 2018; Accepted February 282018

Abstract: From the very beginning of civilization, economic reality and words have been intertwined with religions and vice versa. It would be enough to think at the phenomenon of sacrifice, that is, the first "language" that religions used to communicate with the divine. In the Western culture, a deep cross-fertilization between theology and oikonomia has occurred in both the Old and the New Testament. In addition, modern political and civil economy, namely the Northern and Southern European economic traditions, can be properly understood in relation to Christian religion in its Catholic and reformed humanisms. These two different spirits of capitalism have still important effects in today's US and EU ways of understanding the nexsus between market and society. In this paper, the author explores some of the issues where these differences in spirit are more relevant (i.e., gratuitousness and meritocracy) and then concludes with some hints about the nature of a different "spirit" of capitalism, that is coming from the Catholicism.

Keywords: Capitalism • Religion • Protestant ethics • Meritocracy

\section{Introduction: economics and theology today}

From the very beginning of civilization, economic reality and words have been intertwined with religions and vice versa. It would be enough to think at the phenomenon of sacrifice, that is, the first "language" that religions used to communicate with the divine. Sacrifice is, basically, an economic reasoning applied to the relationship with gods. It is, in fact, a commercial exchange, where men offer something precious (animals, or even children) to gain some credits toward the divinity. More in general, in the Western culture, a deep cross-fertilization between theology and oikonomia has occurred in both the Old and the New Testament. In addition, modern political and civil economy, namely the Northern and Southern European economic traditions, can be properly understood in relation to Christian religion in its Catholic and reformed humanisms.
Not by chance, the philosopher Benjamin (1921) wrote that "capitalism is a religion, that is to say, capitalism essentially serves to satisfy the same worries, anguish, and disquiet formerly answered by so-called religion. Then, capitalism itself developed parasitically on Christianity in the West" (1986[1921], p.102). According to Benjamin, capitalism is a new form of religion that calls for an exclusive form of worship and replaces Christianity, because it spawned from Jewish-Christian humanism (Nelson 2010). According to this view (that is consistent with Marx's vision of capitalism, less with Weber's: see Weber 1976; Fanfani 1934; Barbieri 2013), modernity is not characterized by a disenchantment of the world, but instead by the affirmation of a new religion, i.e., by the transformation of the Christian spirit into the new "spirit" of capitalism. In modern times, the deep and crucial links of capitalism to the protestant ethics were a central issue in sociology, and the issue of providence has been central not only in Adam Smith but also 
in the foundations of the whole modern political economy, from the Neapolitan G. Vico and A. Genovesi to the French Physiocrats or la sect de les économists, as first underlined by Viner (1972) and Hirschman (1977). ${ }^{1}$

Capitalism borrows from the vocabulary of the Bible (debt, credit, trust, even salary, or profit). In addition, we cannot understand the economy and society of the Middle Ages, the Reformation, or modernity unless we take into account many interplays between grace and money.

As it is well known, a key period in the interconnections between theology and the economy is the Protestant Reformation and Catholic Controriforma in the 16th-17th centuries. Before this crucial crossroad of Western civilization, market economy had growth as a unique European movement, from Sicily to London and from Lisbon to Prague. Christian faith had represented the new philia (fides) that, as in the polis of Aristotle and Pericles, made possible trust and trading among different people belonging to different clans and villages. The fiere along the big rivers of Europe was the hubs of complex networks of commercial, artistic, and cultural relationships that sprung into the civic humanism and Rinascimento of 15 th and 18th centuries. The scholastic philosophers and theologians - Aquinas over all, for his huge influence over the second Middle Age social, philosophical, and economic syntheses - have built up a first ethics of the proto-market economy based on the pivotal idea of common good, namely the thesis that the good of the individual has to be seen in deep and necessary connection with the good of the community. A conception of economy - money, usury, just price, etc. ontologically communitarian and hierarchical, came from that vision, because the mediators (priest, king, father, etc.) were the basic mechanism to implement the harmonization of public and private goods. Furthermore, in the late Middle Age, the connections between market and religion had reached a very huge dimension: indulgences, poor people paid by the rich ones for making prayers and penitence in their place, donation of bankers for buying reduction in years of purgatory, etc.

Martin Luther reacted against at least two elements of the southern Christianity: a) the excessive and often insane mixture money-grace, b) the magnificence of Rome and Italy that were also the fruit of the wealth created by a new and positive attitude toward luxury and money during the 14th and 15th centuries. Luther was deeply impressed and shocked by the mundane and market-based society he met in Italy, which considered far from the original message of austerity and poverty of the gospel. The strong reaction of Lutheran and later

1 Bruni et al. (2016), Wicksteed (1910), Sella (1930).
Calvinist Reformation was not only against the theology of the Roman church but also against the style of living of Italian Renaissance, its palaces, masterpieces of art, Michelangelo, and Leonardo. Therefore, the protestant cultural program was also a reestablishment of a more authentic and less money-oriented society; but, paradoxically, due to the elimination of the hierarchical mediation of the church, the protestant culture created an environment much more adapted to develop the capitalist economy (Barbieri 2013). In fact, while in the Southern Europe, the counterreformation stopped the process of freedom in commerce and politics started with the civic humanism; in the northern protestant countries, the individual freedom was the engine of capitalistic revolution. Then, there was the northern protestant Europe where the civic humanism and Renaissance tradition continued; whereas in Roman Catholic countries, such as Italy or Spain, there was a re-feudalization of the society that brought back those countries into a situation close to the Middle Ages before civic humanism.

The mediation of the Roman Catholic church is a very key point here. Unlike the protestant world, in the Roman context, the church and its institutions played a central role in the legislation regarding commerce and money, using a theological vision - that of the scholastic, of Aquinas in a special way - written in a different historical period (13th to early 14th centuries) more static and based upon Aristotelian categories (sterility of money, etc.) that in the Rinascimento were not anymore able to encompass the new economic reality after commercial revolution of the Italian and European cities. As underlined in the early 18th century also by Scipione Maffei, the mediation and control of the institutions of the Catholic church upon individual economic activity, and the strong tools of implementation of this control (i.e., Inquisitione), made the countries of the Southern Europe (Italy, Spain, Portugal, and part of the France) in a condition of economic and financial disadvantage with respect to Northern Europe. In fact, due also to a lack of religious hierarchy, in Holland and in other protestant countries, financial and money landing were allowed, and therefore, there was the growth of commerce and wealth (Barbieri 2013). Parallel to this, whereas in the north Europe and later in the USA, thanks to Calvinist ethics, labor and business were considered to be moral ways of engaging in ordinary life, in Italy after the Controriforma the re-feudalization of the culture produced a new praise for rural life and diffidence toward urban life (and its commerce). In addition, the condemnation of money landing and usury knew a new season in Italy in the Seicento, that contrasted with what was going on in northern part of Europe - Bentham's "defense of usury" is a radicalization of a widely shared idea in this context. 
It is true that most ecclesiastic, political thinkers and theologians of the post-Controriforma season were laudatores of labor, but the praised labor was agricultural and intellectual work, whereas the manual or artisan's activity in the cities (smiths, carpenters, shoemakers, etc.) was considered to be not noble and servile.

There was a period of thought from the end of the 1800s until the 1930s in which there was great interest in the historical causes and roots of modernity, its relationship with the Reformation, and the reactions against it (we summarily calls this the Catholic counterreformation, knowing that the expression was and is ambiguous). Giuseppe Toniolo, Werner Sombart, Lujo Brentano, Gino Luzzatto, Fanfani, and Weber were historians and social scientists who made the thought and work of Martin Luther and the other 16th-century reformers (Calvin in particular) the axis around which they reconstructed the coordinates of modernity. They gave special attention to the birth of capitalism, which they considered an ethos, or "spirit" of modernity, thus something far more general and pervasive than just the economics (production, savings, circulation, and consumption) of European and Western societies. The historical analysis of the "spirit of capitalism" has been in a long eclipse from the 1930s to today. Recently, however, there has been a renewed interest on the part of historians and social scientists in the origins of capitalism and its spirit. Among these are the French authors such as Chiapello and Boltansky (2007), who called their important work The New Spirit of Capitalism. For Chiapello and Boltansky, what characterizes the modern spirit of capitalism is its capacity to "recycle" and incorporate the major criticisms made of it during its history (and primarily those made recently) and then turn them into the main factors of change and innovation. Thus, the "social" criticisms (socialist, communist, cooperativist, labor, and environmental), rather than provoking its collapse, as they might have done, became its cornerstones at the end of the 20th century, giving life to a new capitalism, a new "spirit." This is true in companies as well, primarily in large multinational firms, in which we are seeing the development of social balances and social businesses with attention to worker well-being, equal opportunities, and even the recent concepts of corporate "symbolic" or "spiritual" capital. In parallel with the inclusion and transformation of social criticism, this capitalism has also internalized esthetic criticisms, giving life to a new season of creativity. The main giants of the new economy, such as Google and Apple, have made "creatives" - their new entrepreneurs and lead players. In chameleon-like fashion, capitalism is transforming itself, finding sustenance in whatever it finds along the way. For Chiapello and Boltansky, this capacity to change and incorporate criticism is the new spirit of capitalism, which preserves very little of its old Calvinist origins.

These two different spirits of capitalism have still important effects in today's US and EU ways of understanding the nexsus between market and society. In this paper, the author explores some of the issues where these differences in spirit are more relevant (i.e., gratuitousness and meritocracy) and then concludes with some hints about the nature of a different "spirit" of capitalism, that is coming from the Catholicism.

\section{The challenges of gratuitousness}

\subsection{Sine merito: without merit}

This was how the first so-called Mounts of Piety (Monti di pietà) were referred to from the Middle Ages to modernity. These were prototypes of the community banks created and promoted by the Franciscan "observants" (Order of Friars Minor). To emphasize their nature as humanitarian or philanthropic institutions, the presence of merit was denied. A few centuries ago, Bernard of Clairvaux described the passion of Christ as donum sine pretio, gratia sine merito, charitas sine modo (gift without price, grace without merit, love without measure): saying gift excluded a price, saying love eliminated measuring, and saying grace denied merit - merit, price, and measure, on the one hand, and gift, grace, and charity on the other hand.

These distinctions and oppositions have held up the ethos and spirituality of the West for many centuries, until the capitalist culture, with its new Pelagian - and therefore meritocratic - religion has finally convinced us that all those words were actually on the same side, sisters and allies, that the gift would go along with the price, that merit was a new name for love, and that grace/gratuitousness was only useful if present in the "right" (microscopic) measure, as in vaccines where a tiny dose of the virus is introduced into the body to immunize it from the same.

The greatest human innovations occurred when inside a religion, a philosophy, or a wisdom tradition someone broke the retributive-economic relationship with the gods, the idols, or the pharaohs and kings and proclaimed a jubilee of the "liberation of prisoners." One of these great anthropological and theological innovations is contained in the Book of Job, the book of the Bible that fought the retributive-economic logic of faith the most. The book opened with a bet between God Elohim and his angel Satan which was precisely about gratuitousness. Satan, we read in the prolog, has returned 
from a trip on the earth, and having noticed the uprightness of Job, he asks God: "Does Job fear God for no reason? You have blessed the work of his hands... But stretch out your hand and touch all that he has, and he will curse you to your face" (Job 1, 9-11). ${ }^{2}$ It is interesting that the author of the story chose Satan as an exponent of the "economic" vision of religion and life - a choice that in itself says a lot. Satan challenges Elohim and Job, he challenges God and man, to test whether it is possible that there is at least one man on earth who loves and fears God "for nothing," i.e., freely, without a reward, without being paid for it.

Can we be good and just for the intrinsic value of goodness and justice, or only because we are hoping for some reward? Are we capable of pure love, or, rather, are we only in a commercial register of give and take? It can be understood that the idea of gratuity is deeply tied to that of freedom: What is left of our freedom and that of others if, in fact, at the heart of our actions there is a boss who pays us to do what he wants? Therefore, the first one to be liberated in any greater remuneration religions, past and present, is God himself, who finally steps out from the palaces of kings and emperors and comes to live among us.

No wonder then that some decisive stages of human history have been marked by debates, schisms, and revolutions that had to do with gratuitousness directly. What is it that really saves us? Is it the merits, incentives, the profit, or is it something else and precisely because it is not merit, it is not incentive, it is not profit? Do we have value and infinite dignity only because we deserve it, because we are useful to someone, for something, or rather for some other reason that comes before all of these? That is where the nature of that dimension we call gratuitousness lies, in its essence. Cultures, religions, and philosophies have declined it in many ways, but in its core it has this dimension of the nonprofit, non-merit, and non-incentive. The constant resistance to affirm the logic of the market that, until recently, civilizations have always shown stemmed from intuition and was formulated in various ways. It says that whenever human relationships assume a mercantile registry, there is an invincible tendency to drive out and destroy just that something vague and difficult to define; that subtle and essential thing is called gratuitousness.

The incentive is now the main instrument by which the capitalist cult is eliminating gratuitousness from the world of men - there will always be plenty of gratuitousness in nature: in the sun, in the sky, in the lives of animals, in the rain, in the snow, and in children. Each idolatrous worship tends, in fact, toward the elimination

2 On this, see the comment to the Book of Job (Bruni 2016) of every intrinsic dimension in our actions. As long as we do something because we believe in it or because we like it, we are still not the prisoners of idols. The ideology of incentive produces the emptying of the intrinsic dimension of the action precisely because by assigning a price to everything and every act; it ends up expelling gratuitousness from the world. The incompatibility between gratuitousness and the ideology of incentive is radical and points out precisely at Satan's argument: it is not possible for people to do good things for free, "without being paid." Faith in the incentive is spreading unabated everywhere, because, paradoxically, it comes as an expression of the "freedom of the modern."

\subsection{The hidden costs of meritocracy ${ }^{3}$}

Merit is the great paradox of the economic cult of our time. The first spirit of capitalism was generated from the radical critique of Luther's theology of merit, but that "rejected stone" has now become the "cornerstone" of the new capitalist religion that is emerging from the heart of the very countries built on that ancient antimeritocratic protestant ethics. Salvation for sola gratia and not through our own merits was placed at the center of the Protestant Reformation.

"The world meritocracy has many merits, but clarity is not among them." This sentence of Sen $(2000$, p.5) is a good starting point for a critical reflection on merit and "meritocracy" (Young 1958). According to Sen, the lack of clarity is due to the fact that the idea of merit is "deeply contingent to our view of a good society" (ibid). Each society, in fact, has its own theory of good and therefore of merit, a central idea in one of the first books on merit - Del merito e delle recompense - by the Italian economist Gioja; in 1818, he wrote: "The ideas in the minds of men correspond to the word substance, shall, as everyone knows, be infinitely different: they change the subject, grade, purpose, measuring not only between nations and peoples, but likewise between classes and classes of the same city" (1853[1818], p.35).

The logic of merit has always been very powerful, also because it is often and naturally linked to the idea of virtue and good. Its myth is growing in our age, as if it were a simple thing (Frank 2016). People have always tried to react to this scenario that appears to us as a great display of injustice. In ancient civilizations, the main solution to injustice in the world was to imagine a God who is different from us and follows a fair policy of rewards and punishments. They took the historical fact of inequality and injustice and gave reality a religious chrism. The apparent injustice was thus turned into an invisible and

3 This session develops some ideas already present in Bruni (2018) 
deeper kind of justice, and the world was given order by finding a religious sense in richness and in their own misfortune or that of others. Therefore, those who were rich and powerful were granted the status of "blessed" without calling them for conversion, and those who were poor and unfortunate were sentenced twice: by the misfortunes of life and by God. This vision of God is also at the basis of the socalled 'theology of prosperity'.

The moral needs to recognize the merit that produced an immense sense of guilt in the poorest and the most unfortunate for their own misfortunes. Other forms of religious humanism have instead reacted by imagining that the injustice under the sun would be eliminated in other lives beyond the sun, where the poor but righteous would be rewarded and the rich but wicked punished. The earth is unjust, buy the heaven is not. The economic-retributive logic remained, but the horizon of its application stepped out of the historical time span to eternity or at least to another life. Theories about merit necessitate a humanism of morally different individuals, where everyone has their own "card" of actions/rewards. Holistic societies are not meritocratic.

Because of its humanistic and personalistic spirit, meritocratic ideology (which makes merit the criterion to evaluate, classify, and order people and organizations) is charming and seductive, and it captures many people. We find it at the center of the culture of large corporations and multinational banks. Its symbolic technology is of a dual nature. On the one hand, large enterprises build a sophisticated system of incentives designed to identify and reward merit, which is conceived according to the business objectives. On the other hand, the worker who finds himself in this rewarding mechanism reads his own salary and benefits as a signal of his meritability. It is a perfect contract, continuously fed by both sides because it seems mutually beneficial: the company satisfies its need for rationality and ordering reality to its own ends, and the employees meet their need to feel worthy and valued. It is an ideology that has grown like climbing grass on the retributive tree in the garden of biblical faith, and it is experiencing an incredible growth and success in the era of individualistic capitalism. As Weber showed, in Judeo-Christian humanism, there is a stream that has interpreted economic success as a sign of election and salvation. The current economic culture has radicalized and universalized the psychological-religious mechanism. It secularized and extended it from the entrepreneur to the entire economic system, production, finance, and consumption. The quantity and quality of salaries and incentives (and consumption) become the new indicators of election and predestination for the "paradise" of the deserving (meritable). The symbolic-religious dimension of money and success has thus been amplified, radicalized, and generalized.

Actually, merit is an ambiguous word, rarely a friend of people and the poor - and even more valid for meritocracy. The evangelic logic of the "worker of the last hour," one of the most beautiful pages ever written, is a critique of the idea of merit that is no less radical than that of books of Qoheleth or Job. Let us think about the Book of Job. In the "economic" religions of the past (and also in those of today, in our big enterprises and banks), misfortune and impurities are considered as the effects of a life as a sinner. It is this equivalence that the Book of Job does not want to accept - either for Job himself or for us. From being a rich and powerful man, Job suddenly found himself unfortunate, impure, and therefore untouchable, excluded from all the social castes. This is still the sad fate of entrepreneurs, managers, workers, politicians, and priests who, having fallen into disrepair, find themselves not only impoverished but also sitting on a pile of rubble which includes family, friends, and health. In addition, they immediately end up among the unclean, cast out from the village, marginalized by the clubs, associations, and groups, which are confined in social and relational landfills, shunned by all, and never touched for fear of being infected by their ruin. At the heart of the story of Job, there is also a religious and anthropological revolution that seeks to overcome the remunerative vision of faith (our wealth and our happiness are the prize for a faithful life, ours or that of our fathers), which has also been central in the ethics of capitalism.

This argument against retribution, which is also present in much of the prophetic and sapiential traditions, was very valuable among the Jewish people who have always been tempted to read their experience with $\mathrm{YHWH}$ Elohim through commercial categories, starting with the very structure of the covenant. The faith of Israel was, in fact, born within the cultures of Mesopotamia, where it was normal to see religion as an exchange/commercial relationship with a sovereign God. Religious practices, in their archaic origin, normally arise as idolatrous practices of a commercial type. Those who manage to evolve and break free from their primordial forms, gradually abandon the logic of do-ut-des with respect to the deity. Much of the effort that the people of Israel made was generated by the process of liberation from a merchant God who gave grace and indulgences in exchange for vows, sacrifices, and offerings. Without the prophets, without Job and Ecclesiastes, this process would have imploded, and the religion of Israel would have remained one of the many Canaanite cults. But the temptation of an "economic" religion is inherent in every religion, and without the necessary care and attention one may end 
up back in the ancient idolatrous cults, turning Elohim into a King hungry for offerings and submission statements to grant protection.

Therefore, the religion becomes a "double entry accountability" between the faithful and gods again, where sacrifices and vows become the currency (not only in a metaphorical sense) of this business. An economic religion that has always had (and have) many followers just because it is easy is simply stupid, said Qoheleth the "sacrifice [is] of the fools." The believer is happy to purchase "merits" and compensate faults by simple sacrifices, and the administrators of religion draw much economic advantage and control over consciences by fueling this vile trade. It is not a coincidence that the episode of Jesus with the merchants in the temple (John 2,14-16) is placed at the very beginning of his public life, and we can understand it clearly if our point of departure is these pages of Qoheleth. Christianity had to fight a lot in its early phase to announce a religion of full gratuitousness, and whenever it stops this fight always falls back to being an ancient idolatrous cult. We need a great deal of work and care not to exit from the horizon of gratuitousness, falling back on the registers of merit and fault.

The Bible's criticism of merit is vital if we want to understand the inherent dangers in a whole social life built on the logic of merit as it is conceived and promoted by companies. We could have imagined another capitalism that is less anchored to retributive religion and would almost certainly have a less sick planet and healthier social relationships; but today, we must at least prevent its logic from becoming the culture of the full scope of social life. Instead, incentives and meritocracy are increasingly occupying many noneconomic areas.

The great task of Christian humanism, at the hearth of Europe civilization, was liberation from the retributive culture that dominated the ancient world and from assigning guilt to all the misfortunate. We must not resign ourselves to selling it off for the "lentil stew" of merit. We are worth a lot more.

Meritocracy was also a revival of Augustine's polemics against Pelagius (Luther was an Augustinian monk), a millennium later. The anti-Pelagian criticism was essentially a surpassing of the ancient idea that the salvation of the soul, the blessing of God and heaven, could be purchased, bought, or earned by our actions. The theology of merit also wanted to imprison God within the meritocratic logic, forcing him to punish and reward, based on criteria attributed to him by theologians.

The fight against Pelagianism was a far from marginal operation. It was decisive for the Church of the first centuries (a struggle that in fact, as we can see, has never been won). If, in fact, the Pelagian theology had prevailed, Christianity would have been added to the many apocalyptic and Gnostic sects of the Middle East or transformed into an ethic similar to stoicism. It would have lost the charis (grace, gratuitousness), which was its specific feature and clearly distinguished it from the religious doctrines and the dominant meritocratic idolatries.

The origin of the meritocratic type of religion is therefore very old, and it hides deep within the history of religions and idolatrous cults. In continuity with the prophetic soul of the Bible, the message of Christ was a real revolution in a theological world dominated by economic/retributive cults and by merit. To see this and get a very clear idea of it, just reread the dialogs of Job with his friends. Although we found some remnants of merit in the Gospels and in the New Testament texts, the words and life of Jesus were above all a radical critique of meritocratic faith and continued and developed by the theology of Paul. To understand this, it is enough to take the parable of the worker of the last hour, where the wage policy of the "owner of the vineyard" follows a radically anti-meritocratic criterion, or to consider the role of "elder brother" in the story of the "prodigal son" who scolded their merciful father just because he had not followed the meritocratic rules about his brother. Mercy is the opposite of meritocracy: we are not forgiven because we deserve it, but it is precisely the condition of being undeserving that moves the bowels of mercy. The Beatitudes are an eternal, forming an eternal manifesto of non-meritocracy. In his Kingdom, there exists a different law: "be (the) sons of your Father who is in heaven. For he makes his sun rise on the evil and on the good." The perfection of this ethic is the definitive surpassing of the register of merit: "You therefore must be perfect, as your heavenly Father is perfect" (Matthew 5).

Despite the clarity and strength of this message, the old economic-retributive-meritocratic theology continued to influence Christian humanism throughout the Middle Ages and well beyond. Neo-Pelagian ideas continued to inform Christian doctrine, and especially its practice, until the real disease of the "market of indulgences," that can be understood only in the framework of a deformation in the retributive-meritocratic sense of the Christian message. In addition, as always happens in matters of religion, the consequences of these theological ideas were (and are) immediately social, economic, and political. Those considered undeserving were (and are) also condemned and marginalized, and the deserving attained paradise on this earth, before winning it in the other life, since their merits were associated with many privileges, money, and power.

The history of Christian Europe has been a slow process of getting rid of this archaic vision of faith in a historical succession of several more Augustinian 
and Pelagian stages. But until recently, we had never thought of building a wholly, or predominantly, meritocratic society. The army, sports, science, and schools had a tendency to become meritocratic, but other decisive spheres of life were governed by a different and sometimes opposite rationale. In churches, in the family, in healthcare, and in civil society, the basic criterion was not merit, but need, another great word now forgotten and replaced by consumer tastes. School, for example, is a place where none, or few, have questioned that the merit system should be the prevailing one (although not the only one) in the training and assessment of children and young people.

But we should not think that this choice, which seems noncontroversial, did not for centuries result in very serious consequences. Based on merits and school grades, we have built a whole social and economic system that is caste based and hierarchic, where the first places were taken by those who responded best in this merit system and the lowest ones by those who performed worst at school. And so, doctors, lawyers, and university professors have had much better wages and social conditions than workers and peasants; currently, in this new wave of Pelagian meritocracy, workers who, by working day and night, keep the streets and sewers clean receive salaries that are hundreds of times lower than those of the managers of the companies for which they work.

Currently, it would be more urgent than ever to return to Augustine's ancient criticism of Pelagius. Augustine did not deny the existence of talent and commitment that generated those actions or ethical states which we call merits (from Latin merere: earn, wages, profit, prostitute). The decisive point for Augustine was about the nature of these gifts and merits in people. For him, all these were charis, grace, and gratuitousness. According to Augustine, "God does not crown your merits as your merits, but as His own gifts." Merits are not our merits except in small part - a part that is too minimal to make it the main wall of an economy and a civilization. That is why an important side effect of a culture interpreting the talents received as merit and not as gifts is a dramatic scarcity of true and sincere gratitude. The first characteristic of merit systems, in fact, is mass ingratitude.

Actually, when we tie social esteem, remuneration, and power to talents and so to merits, all we do is extend and greatly amplify inequalities. People who are unequal already at birth because of their natural talents and family and social conditions become even more so as adults. In the 20th century, particularly in Europe, politics reduced the gap in the points of departure in the name of the principle of equality. Our meritocratic age, however, strengthens it and takes it to the extremes. Therefore, if I am the son of educated, rich, and intelligent parents, if I was born and grew up in a country with many public goods and good health and education systems, and if my initial set of chromosomes and genes was particularly lucky, it follows that I shall attend the best schools and will attain more academic merit than my peers who were born in more unfavorable natural and social conditions, and that in all probability I will find an employment in the labor market that is much better paid by the merit system. And so, by the time I retire, the distance from my fellow citizens who came into this world with less talent will have been multiplied by 10,20 , or 100 .

That is why we do not understand the increase in inequality in our time unless we take its root very seriously: the sharp increase in the presence and influence of the merit theology of capitalism. In addition, we do not understand the increasing blame placed on the poor who are seen more and more as undeserving instead of unfortunate if we do not take the undisturbed advancing of the meritocratic logic into consideration. If, in fact, I interpret the talents I received (from life or from my parents) as merit, the step of considering those who do not have them unworthy and guilty will also be taken readily and all too soon. The axis of meritocratic worlds is not heaven, but hell and purgatory. Demerits and guilty are the protagonists of the empires of merit.

\section{The Catholic spirit of capitalism ${ }^{4}$}

The historian Fanfani's work has important things to say about the nature of the Catholic form of capitalism. Fanfani (1908-99) was among the scholars who, on an international scale, dug most deeply into the relationship between Christianity, the Reformation, the counterreformation, and economics; his work awaits rediscovery today. Fanfani's starting point was the contrast between the medieval era and Renaissance and humanism. In the Middle Ages and here, he echoed some of Jacques Maritain's themes in integral humanism - the center was God. With humanism, humanity became the center, and individualism its usual characteristic, which was expressed in all spheres of human endeavor, from economics to art. In the Middle Ages, economic ethics were dominated by the idea of justice and by the principle of being content with one's status. Thus, seeking and accumulating "excessive" wealth were condemned (primarily by Thomas Aquinas). Each should seek wealth "adequate" to one's needs, without ambitiously seeking an excess; accepting one's lot was what upheld the social

4 This sessison is based on the study by Bruni and Zamagni (2016, chapter 5). 
order organized into strata, classes, and groups. Fanfani, however, after showing the conflict between Catholic and capitalist ethics, posed a question that we find today intact at the center of the work of the contemporary American historian, Gregory (2012). Fanfani (1934) wrote: "if Catholicism has fought the capitalist spirit, then and always, why did it manifest itself in the Catholic era?" His response was that the pre-Reformation spirit of capitalism emerged from several "deviations" that were due to new realities during the 1400s and 1500s: international commerce and merchants' actions that were beyond local control; the expulsion of Jews from the south to the north Europe; the displacement of commerce from the Mediterranean to the Atlantic. For Fanfani, the Protestant spirit is just one of these new realities.

The central point of Fanfani's critique is that the real conflict that led to the Reformation was not theological, but rather a conflict between two civilizations: the Germanic world and Italian and Latin humanism. Fanfani wrote: "When the Germanic world came into contact with the Latin world, which had been refined by Renaissance manners, it withdrew in horror. Luther harshly judged the nature of the renewal and reacted" (Fanfani 1968, p.508). Indeed, for the Italian humanists,

the world appeared to be a garden of delights, populated by inhabitants preoccupied with improving hospitality, and deepening the powerful gifts of ingenuity in imagining new juxtapositions and combinations. In the words of the humanist Coluccio Salutati, the happy creatures did not deny the initial creative intervention of a beneficent God, but they reasoned "as if there were no God." Humanity appeared at the centre of society. [Thus] the Reformation, which formally began and took strength from him [Luther], was first of all a protest, then a restoration.... in the eyes of his initial followers the world in which humanity dominated was heretical, the society in which neighbours, goods, time, ingenuity, and worship were about making the enjoyment of life easier for the individual. (Fanfani 1968, p.508)

This theme was not dissimilar to Weber's: "And what the reformers complained of in those areas of high economic development was not too much supervision of life on the part of the Church, but too little" (Weber 1976, p.5). This statement seems bizarre to us (because we have forgotten the importance of the religious element in life), but if purged of a certain apologetic vein in defense of the Catholic world and a thinly veiled anti-protestantism of that time, it retains a certain heuristic capacity, primarily for a discourse on capitalism. Luther's protest - and Calvin's even moreso -was against civic humanism and the Renaissance, as well as against the theological deviations (such as indulgences) and the clergy's way of life. Fanfani wrote:

The Latin world reacted against the Protestant criticisms, but the reaction was predominantly ecclesiastical. The Counter-Reformation, while sharing early Protestantism's criticisms of humanistic and Renaissance ideals, distinguished these from its own; it acted such that people would make use of the arts and letters that Civic Humanism and the Renaissance had rediscovered and perfected in order to lead a life enlightened by Christian ideals. (Fanfani 1968, p.509)

For Fanfani, "Humanism-Renaissance and Protestantism unfolded along the same track, in that they were moments of the same revelation that humanity did to itself: the 'naturalistic' revelation" (Fanfani 1968, p.509). At this point, Fanfani's discourse opens onto a highly relevant theme: humanism-Renaissance and the Protestant Reformation were two reforms of the medieval spirit, two different transitions from "voluntarist" doctrines (i.e., human beings are "diseased" and their natural passions and interests must be oriented toward the good by institutions, and thus by the hierarchy) to "naturalist" doctrines (individual natural interests are good tout court). Thus, the counterreformation sought to restore the Middle Ages, while the Protestant Reformation more forcefully continued the work of humanism and the Renaissance. Hence, the distinction between

The northern countries, in which Reformation individualism was oriented towards production and the creation of wealth, and Catholic countries (also due to the weight of classic Roman culture), in which the Counter-Reformation blocked that subjectivist revolution and returned the world to medieval ethics-ending up however accomplishing nothing except encouraging conspicuous, positional consumption and discouraging corporate economic activity and work. (Fanfani 1968, p.512)

The Catholic Church reacted against the values of the Reformation by questioning the values of humanism and the Renaissance against which the Reformation had inveighed, and in so doing ended up obstructing the process of European humanism, which was constructing a market economy based on liberty. That is why the northern cities of Europe gave life to capitalism, while the Latin cities saw a restoration of antimodern values, especially rents and consumption. In other words, according to Fanfani, the Reformation and the consequent counterreformation blocked 
the humanist process that began in the Middle Ages and gave rise to civic humanism and a capitalism that was at once personalistic and communal, a capitalism capable of melding individual liberty and the common good, with a fundamental role played by the great medieval charisms, theologians, citizens' institutions, and their liberty within the city walls. From one aspect, protestantism criticized humanist and Renaissance customs, and it was much less conspicuous in the trappings of wealth than the Catholic Church of that time. However, by eliminating the church's mediation and control in citizens' lives, it ended up creating a climate of unmediated liberty for people, in which capitalism developed in its own way (although without the social dimension, except for philanthropy and restorative ethics) - in the market economy of the 14th to the 17 th centuries.

The Reformation is a noteworthy case of unintended consequences, although not the only one in modernity. Luther and the other proponents of the Reformation (except Calvin) were hostile to economic questions, not knowing how market institutions operated. Theirs was an impassioned fight against the widespread practice in the Catholic Church of incidents of corruption and commerce in indulgences. The Reformation did not pertain, except indirectly, to the ethical sphere. It was focused rather on theology and religious life. In addition yet, preoccupied as he was with protecting religion from the influence of market forces, by affixing his 95 theses to the Wittenberg cathedral door Luther wrote - according to some interpreters of Weber's work - a capitalist manifesto. Is there any truth to that? We really do not think so. In the first place, contrary to the assertions of no small number of interpreters, Weber never maintained that capitalism originated in the Reformation. Weber in fact wrote:

We have no intention whatever of maintaining such a foolish and doctrinaire thesis as that the spirit of capitalism (in the provisional sense of the term explained above) could only have arisen as the result of certain effects of the Reformation, or even that capitalism as an economic system is a creation of the Reformation. (Weber 1976, p.91)

According to Weber, it is not so much capitalism per se as it is modern capitalism that requires an explanation of its origins, or better yet, of its rapid spread in the Northern European countries. Note that in contrast to Luther, whose knowledge of economic problems was rather limited and whose hostility to capitalist practices was well known, Calvin was fully aware of financial practices and their economic and social implications in Geneva, where he lived. One can support the view that, although bourgeois values such as frugality, perseverance, and dedication to one's work and so forth all received explicit recognition in Calvin's theology, modern capitalism (in Weber's sense) is more a collateral result than the expected outcome of that religious perspective - a perspective in which salvation is something individual rather than communal. While for Catholic theology $\sin$ is destructive of the unity of the human race, for protestant theology sin is the rupture of the individual bond that unites one to God; this is how salvation becomes an eminently individual fact. The practical consequence of such a change in perspective was that Catholic social works were eliminated in countries touched by the Reformation; that is to say, one of the highest expressions of the centrality of the common good was abandoned. That in turn had the effect of transferring a sizeable amount of resources from social to economic use, thus favoring the process of capital accumulation. To put it another way, the Reformation not only influenced the demand side - as most hold - by altering people's dispositions and preferences toward a higher propensity for work and saving but also the supply side, resulting in a substantial reduction in the cost of services and religious practices. Eliminating the hierarchy, indulgences, pilgrimages, and other religious rites, building modest churches, and so forth, had the effect of freeing up scarce resources (labor and capital) and channeling them toward economically productive uses.

The large-scale anti-feudal movement during the 18th century in Southern Europe, or the providential vision of the market and commerce - one need only to consider Genovesi or Dragonetti in Catholic Enlightenment Naples in the second half of the 18th century cannot be understood apart from a Catholic Europe that, after the 16th century, did not find its way back to a "civil" market for two or three centuries and that, in place of the civil and commercial virtues of Siena, Florence, Venice, and Marseilles, had established rural virtues and virtues in consumption. Then, as now, in a Europe seeking a way toward the market and civil society, there was a need for a civil economy.

Due to its "Catholic" origins, the civil economy, and more generally the European and Italian economic and political traditions, has always taken a voluntaristic approach (consider the mixed economy, for example, and the great weight of the state in the economy) until recent times, when conformist mainstream thought originating in naturalism has become dominant. The voluntaristic approach requires economic behaviors to be tempered by the society to ensure growth, and thus the common good, for everyone (not just the most talented 
or those who have a competitive head start). The theories of just price, salaries, money, and usury as stated by Aquinas, Nicola d'Oresme, Bernardino da Siena, Botero, Antonino da Firenze, and many others are part of this voluntarist tradition, including the Franciscans (whom a certain "naturalistic" reading of the history of economics tends to place in its camp). It is not so much that the medieval theories did not grasp the nature of the market as a positive sum game (this too is found in other authors), nor that they did not understand the incentivizing nature of interests and profits; what is in play here is a vision of society and humanity in which the good does not emerge from selfishness, but from the virtues. Genovesi's civil economy is obviously in the voluntarist tradition as well. Fanfani wrote:

The Italian abbot Antonio Genovesi was the leading figure of all, who in 1754 had the fortune to be the first to occupy a university chair in economics in Naples, and who systematically organized the entire modern voluntaristic doctrine in a fully developed form in the Lezioni di economica civile (Lessons in civil economy). ... Genovesi wrote in the preface to the Italian translation of John Cary's Essay on the State of England, "Nature gives people instincts, but the government must give form and skill." (Fanfani 1942, pp.165.167)

\section{Conclusion}

Most of the current-day differences in labor culture, public debt, private and public ethics, in welfare states, individual rights, and the idea of market lay in the two different ways that Europe took after the reform and Controriforma era. Understanding the peculiarities of civil economy is important to take into consideration its Catholic roots.

The Cinquecento and Seicento were a return to Middle Ages (Aquinas) as far as economic ethics is concerned. The modernization and openness to market of Quattrocento, with the key role of figures such as Bernardino da Siena or Leon Battista Alberti, were not able

\section{References}

Barbieri G., Decline and economic ideals in Italy in the early modern age, Florence, 2013.

Benjamin W., Capitalism and religion, In: Liedemann R., Schweppenhäuser H. (Eds.), Gesammelte Schriften, Frankfurt, 6, 100-103, 1986. to fully flourish in Italy and Southern Europe. Second, the age of Controriforma was - with few exception, such as Menochio - a praise of agriculture and rural life and a criticism to urban and civic activities (i.e., commerce). As a consequence, starting with the second half of the $16^{\text {th }}$-century Latin Europe knew a re-feudalization of the society, and a centrality of rent over profit of merchants and salary of workers. Third, after Reformation, neo-platonic thought replaced the Aristotelian one of the Quattrocento; then solitude, esoteric and magic practices took the place of social and political activities of the Aristotelian vision of Bruni and other civil humanists of the previous century. A thesis was consistent with that of the historians such as Eugenio Garin and Hans Baron, who almost invented the expression of civic humanism to distinguish the first half of Quattrocento.

Finally, theology had a key role of theology for understanding the still relevant differences between the Anglo-Saxon capitalism and the Latin European one. The Southern Europe, its long history characterized by a huge biodiversity, at the apex of Middle Ages had generated a market economy based on Catholic paradigm and then expression of a communitarian and institutionally "mediated" idea of the society. The northern protestant traditions gave life to an idea of the society of individuals without the mediation of intermediate institutions, i.e., the humanism of the "invisible hand" and of the Leviathan: within the space of freedom of the state Leviathan created by the social contract, the common good is not entrusted to the mediation of the institutions but is the non-intentional result of the actions of separated and independent individuals. The Reformation and the Controriforma have been a turning point in the modern Europe, and the contemporary gaps in economic and social terms between the north and south Europe are fruits of an interrupted path. The social pathologies, the "amoral familism" and the corruption of "mediated society," of the Italian and Mediterranean societies are well-known and serious. At the same time, also the protestant humanism, its individualism, is facing a different but not less relevant crisis that calls today for something new too.
Bruni L., La sventura di un uomo giusto, Bologna, 2016.

Bruni L., Hope and the Paradox of Merit: the new dogmas of business religion, In: Van den Heuvel S. (Ed.), driven by hope, Leuven, 2018. 
Bruni L., Oslington P., Zamagni S., Introduction to the special issue on economics and theology, Int Rev Econ, 63, 1-5, 2016.

Bruni L., Zamagni S., Civil economy, London, 2016.

Chiapello E., Boltansky L., The new spirit of capitalism, London, 2007.

Fanfani A., Cattolicesimo e protestantesimo nella formazione storica del capitalismo, Milan, 1934.

Fanfani A., Il volontarismo [Voluntarism], Como, 1942.

Fanfani A., Storia economica, I: Antichità, Medioevo, età moderna, Turin, 1968.

Frank R., Success and luck. Good fortune and the myth of meritocracy, Princeton, 2016.

Gioja M., Dei meriti e delle ricompense, Turin, 1853.

Gregory B.S., Unintended reformation: how a religious revolution secularized society, Cambridge, MA, 2012.
Hirschman A.O., The passions and the interests, Political arguments for capitalism before its triumph, Princeton, 1977.

Nelson R.H., Two gods: economic religion versus environmental religion, Pennsylvania, 2010.

Sella E., La dottrina dei tre principi, Padova, 1930.

Sen A., Merit and justice, in: Arrow K.J., Bowles S., Durlauf S.N. (Eds.), Meritocracy and economic inequality, Princeton, 5-18, 2000.

Viner J., The role of providence in the social order, Philadelphia, 1972.

Weber M., The protestant ethic and the spirit of capitalism, translated by Parsons T., London, 1976.

Wicksteed P.H., The commonsense of political economy, London, 1910.

Young M., The rise of meritocracy, London, New York, 1958. 
